\title{
PERAN GURU PAI DALAM MEMBENTUK KARAKTER PESERTA DIDIK KELAS VII DI SMP MUHAMMADIYAH AMBON
}

\author{
Maida Tranggano ${ }^{1}$ \\ Program Studi Pendidikan Agama Islam FITK IAIN Ambon ${ }^{1}$ \\ E-mail: trangganomaida14@gmail.com
}

\begin{abstract}
The purpose of this study is to find out the role of PAl teachers in shaping the character of class learners VII SMP Muhammadiyah Ambon and to find out the supporting and inhibiting factors of PAl teachers in shaping the character of class learners VII in SMP Muhammadiyah Ambon. This type of research is descriptive qualitative research. This research was conducted from September 22 to October 22, 2020. The subjects in the study were 1 principal and 1 PAl teacher, SMP Muhammadiyah Ambon. The research instruments used are observation sheets and interview guidelines. Data analysis uses data reduction, data presentation and inference. The results showed that Teachers of Islamic religious education in the formation of the character of class learners VII SMP Muhammadiyah Ambon has played a good role, where islamic education teachers have performed their role such as teachers as teachers, namely teachers of Islamic Religious Education has taught about honesty, discipline, manners and accuracy.
\end{abstract}

Keywords: The Role of PAI Teachers, Shaping The Character of Learners

ABSTRAK Tujuan dari penelitian ini adalah untuk mengetahui peran guru PAI dalam membentuk karakter peserta didik kelas VII SMP Muhammadiyah Ambon dan untuk mengetahui faktor pendukung dan penghambat guru PAI dalam membentuk karakter peserta didik kelas VII di SMP Muhammadiyah Ambon. Tipe penelitian adalah penelitian deskriptif kualitatif. Penelitian ini dilaksanakan dari tanggal 22 September sampai dengan 22 Oktober 2020. Subjek dalam penelitian adalah 1 orang kepala sekolah dan 1 orang guru PAI, SMP Muhammadiyah Ambon. Instrumen penelitian yang digunakan adalah lembar observasi dan pedoman wawancara. Analisis data menggunakan reduksi data, penyajian data dan penarikan kesimpulan. Hasil penelitian menunjukkan bahwa Guru pendidikan agama Islam dalam pembentukan karakter peserta didik kelas VII SMP Muhammadiyah Ambon sudah berperan cukup baik, dimana guru Pendidikan Agama Islam sudah melakukan peranannya seperti guru sebagai pengajar yakni guru Pendidikan Agama Islam telah mengajarkan tentang kejujuran, kedisiplinan, sopansantun dan keteladanan.

Kata Kunci: Peran Guru PAl, Membentuk Karakter Peserta Didik 


\section{PENDAHULUAN}

Pendidikan agama Islam adalah upaya sadar dan terencana dalam menyiapkan peserta didik untuk mengenal, memahami, menghayati hingga mengimani ajaran agama Islam dibarengi dengan tuntunan untuk menghormati penganut agama lain dalam hubungannya dengan kerukunan antar umat beragama hingga terwujud kesatuan dan persatuan bangsa. Pendidikan agama Islam memiliki kedudukan tinggi dalam Islam. Dalam belajar mengajar untuk memperoleh pembelajaran yang baik dan memiliki peserta didik yang berahlak mulia dibutuhkan peran guru pendidikan agama Islam.

Peran guru Pendidikan Agama Islam dalam kegiatan proses belajar mengajar menentukan hasil akhir dari peserta didik. Guru Pendidikan Agama Islam tidak hanya dituntut dalam mengajar tetapi harus mampu membina norma moral atau budi pekerti peserta didiknya. Guru Pendidikan Agama Islam sebagai pendidik merupakan seseorang yang memberikan pelajaran dan menanamkan nilai-nilai moral kepada peserta didiknya agar bisa mengembangkan ilmu pengetahuan yang disesuaikan dengan kaidah-kaidah keislaman. Budi pekerti peserta didik menjadi aspek penting dalam kehidupan manusia baik dalam posisinya sebagai individu, anggota masyarakat maupun bangsa.

Penguatan karakter dinilai strategis untuk mengatasi problem moral di tengah kompleksitas kehidupan bermasyarakat. Pembelajaran agama Islam dan moral diorientasikan pada pembentukan karakter dengan penuh kasih sayang, kepada segenap unsur alam semesta. Sebagai pendidik, guru Pendidikan Agama Islam menghadapi tanggungjawab yang berat, untuk itu ia harus memiliki persiapan dan potensi yang memadai. Ajaran tentang karakter sebagaimana yang dicontohkan oleh Rasulullah Saw dalam kehidupan sehari-hari, seperti terdapat di beberapa ayat al-Qur'an yang menjelaskan tentang karakter yang baik Rasulullah. Sebagaimana yang terdapat dalam Al-Quran dari surat Al-Qalam/68 ayat 4:

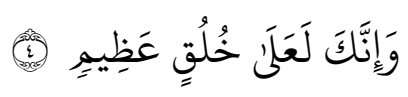

Terjemahnya: Dan Sesungguhnya kamu benar-benar berbudi pekerti yang agung (Al-Qalam/68 ayat 4 ).

Dalam upaya meningkatkan karakter peserta didik seorang guru Pendidikan Agama Islam memiliki peranan yang sangat penting. Menurut Zuhairin, guru Pendidikan Agama Islam merupakan pendidik yang mempunyai tanggung jawab dalam membentuk kepribadian Islam anak didik, serta bertanggung jawab terhadap Allah Swt. Dia juga membagi tugas seorang guru agama Islam, antara lain: mengajarkan ilmu pengetahuan agama Islam, menanamkan keimanan dalam jiwa anak, mendidik anak agar taat dan memiliki budi pekerti yang mulia (Zuhairi, 2003). 
Peran guru Pendidikan Agama Islam dalam pandangan paradigma baru yaitu pihak-pihak sekitar lingkungan sekolah yang berasal dari guru Pendidikan Agama Islam dan peserta didik, untuk memajukan pendidikan yang seimbang antara ilmu pengetahuan dan teknologi dengan iman dan taqwa yang pada akhirnya diharapkan mampu menerapkan pembelajaran. Paradigma pengajaran yang lebih menitikberatkan peran guru PAI dalam mentransformasikan pengetahuannya kepada peserta didiknya bergeser kepada paradigma pembelajaran yang memberikan peran lebih banyak kepada peserta didik untuk mengembangkan potensi dan kreativitas dirinya dalam rangka membentuk manusia yang memiliki kekuatan spiritual keagamaan, berakhlak mulia, berkepribadian, memiliki kecerdasan, estetika, sehat jasmani dan rohani, serta ketrampilan yang dibutuhkan bagi dirinya.

Pemerintah juga melalui Kementerian Pendidikan dan Kebudayaan Nasional memberikan amanah untuk melaksanakan kurikulum 13 (K.13) kepada guru Pendidikan Agama, guru PKN, guru BK dan wali kelas sebagai guru membentuk karakter peserta didik dan penilaiannya yang tertuang pada Kompetensi Inti Satu dan dua (KI.1.2). Jadi jelaslah bahwa guru Pendidikan Agama Islam memiliki peran yang sangat vital dalam membentuk karakter terhadap peserta didik pada masing-masing sekolah. Dalam upaya meningkatkan karakter peserta didik seorang.

Guru PAI di SMP Muhammadiyah Ambon dalam pembentukan karakter peserta didik yakni guru PAI memberikan contoh melalui metode pembiasan yaitu guru PAI menganjurkan ketika bertemu dengan guru atau sesama peserta didik, peserta didik diharapkan untuk menyapa dan mengucapkan salam. Hal ini bertujuan agar peserta didik menjadi terbiasa untuk membentuk karakter yang baik untuk menghargai sesama manusia. Adapun hal lain juga yang dijumpai penulis ada beberapa peserta didik yang masih melanggar tata tertib, walaupun pelanggarannya tidak bersifat berat tetapi harus menjadi perhatian seorang guru PAI yang tugasnya tidak hanya menyampaikan materi agama Islam tetapi harus bisa membentuk karakter peserta didik yang baik. Salah satu contoh ada peserta didik yang masih berbicara yang terkesan kasar dan ketika lewat di depan kelas orang lain yang lagi belajar dan dapat mengganggu konsentrasi orang lain. Selain itu, ketika jam pelajaran ada peserta didik yang ribut sendiri, ada peserta didik berpakaian kurang tidak rapi, rata-rata mereka melakukan hal itu karena karakter mereka kurang baik.

Berdasarkan latar belakang tersebut di atas maka penulis tertarik untuk meneliti dan mengkaji terhadap permasalahan tersebut dan dibuat dalam bentuk skripsi dengan judul "Peran Guru PAI Dalam Membentuk Karakter Peserta Didik Kelas VII SMP Muhammadiyah Ambon". METODE PENELITIAN

\section{A. Tipe Penelitian}

Tipe penelitian yang digunakan dalam penelitian ini adalah deskriptif kualitatif yakni metode pendekatan filosofis yang memberikan gambaran 
tentang situasi dan kejadian secara sistematis dan faktual mengenai faktor-faktor, sifat-sifat hubungan antara fenomena yang dimiliki untuk melakukan akumulasi dasar-dasar, dimana pada umumnya metode ini diartikan secara luas yaitu bukan hanya memberikan gambaran terhadap fenomena, melainkan juga mengupayakan menerangkan hubunganhubungan, memperkuat prediksi, serta mendapatkan makna dan komplikasi dari permasalahan yang hendak dicapai (Lexy J. Moleong, 2000).

\section{B. Kehadiran Peneliti}

Kehadiran peneliti dalam penelitian kualitatif mutlak diperlukan karena instrumen dalam penelitian kualitatif adalah peneliti itu sendiri.Jadi, disamping peneliti bertindak sebagai instrumen peneliti sekaligus sebagai pengumpul data.Sedangkan instrumen-instrumen data hanya bersifat sebagai pendukung saja.Sedangkan peran peneliti dalam hal ini adalah pengamat penuh. Selama melakukan studi lapangan, peneliti sendiri yang berperan sebagai instrumen kunci dalam pengumpulan data karena dalam penelitian kualitatif instrumen utamanya adalah manusia. Peneliti akan menggunakan tiga metode dalam pengumpulan data yaitu: observasi, wawancara, dan dokumentasi.

\section{Lokasi dan Waktu Penelitian}

Adapun lokasi penelitian terkait dengan peran guru PAI dalam membentuk karakter peserta didik kelas VII berlokasi di SMP Muhammadiyah Ambon, dengan waktu penelitian dilaksanakan selama satu bulan terhitung mulai dari tanggal 22 September sampai dengan 22 Oktober 2020.

\section{Subjek Penelitian}

Yang menjadi subjek dalam penelitian ini adalah 1 orang kepala sekolah dan 1 orang guru PAI kelas VII SMP Muhammadiyah Ambon. Jadi subjek dalam penelitian berjumlah 2 orang.

\section{E. Sumber Data Penelitian}

Untuk memperoleh data dalam penelitian ini, maka data penelitian bersumber data:

1. Data primer yakni data yang akan diperoleh langsung dari sumber inti. Data primer tersebut diperoleh langsung dari informan yang berkompeten dalam memberikan informasi yakni para subjek penelitian yang berkaitan dengan permasalahan yang diteliti.

2. Data sekunder yakni data yang diperoleh melalui bahan kepustakaan (Ronny Hanitijo Soemitro, 2000). Dari tersebut diperoleh dari literaturliteratur penunjang seperti buku-buku, artikel, jurnal, tulisan blog internet, dokumen-dokumen penting, laporan hasil penelitian, pendapat para ahli, makalah dan sebagainya dan sumber-sumber terpecaya lainnya.

\section{F. Teknik Pengumpulan Data}

Penelitian dilakukan dengan menggunakan penelitian kepustakaan (library reseach) dan penelitian lapangan (field reseach). Penelitian kepustakaan adalah penelitian yang dilakukan dengan mengutip beberapa 
sumber dan mempelajari teori-teori para ahli serta buku-buku yang berkaitan dengan objek yang akan diteliti. Sedangkan penelitian lapangan memperoleh data dan informasi yang dibutuhkan secara langsung dengan tehnik antara lain yaitu:

1. Observasi yaitu pengamatan yang dilakukan secara langsung ke objek yang diteliti guna memperoleh gambaran yang sebenarnya terhadap permasalahan yang diteliti.

2. Wawancara, metode ini digunakan agar mengetahui dan mendapatkan informasi secara langsung dari para subjek yang dijadikan informan saat penelitian berlangsung di lokasi penelitian.

3. Dokumentasi, yaitu suatu metode pengumpulan data dengan jalan mencatat secara langsung dokumen yang terdapat pada lokasi penelitian berupa; data (fakta yang tertulis), peta, foto, persuratan, maupun data-data yang dianggap penting dan lain sebagainya (Nana Saodih Sukmadinata, 2005).

\section{G. Teknik Analisis Data}

Analisis data merupakan mencari dan menata secara sistematis catatan hasil observasi, wawancara dan lainnya untuk meningkatkan pemahaman peneliti tentang permasalahan yang diteliti dan menyajikannya sebagai temuan. Dalam menganalisa data, peneliti menggunakan teknik deskriptif analitik, yaitu data yang diperoleh tidak dianalisa menggunakan rumusan statistika, namun data tersebut dideskripsikan sehingga memberikan kejelasan sesuai kenyataan realita yang ada di lapangan.

Analisa berupa pemaparan gambaran mengenai situasi yang diteliti dalam bentuk uraian naratif. Uraian pemaparan harus sistematik dan menyeluruh sebagai satu kesatuan dalam konteks lingkungannya juga sistematik dalam penggunaannya sehingga urutan pemaparannya logis dan mudah diikuti maknanya. Matthew Miles dan A. Michael Huberman membuat langkah-langkah analisis yang dilakukan adalah (Matthew Miles dan A. Michael Huberman, 2002).

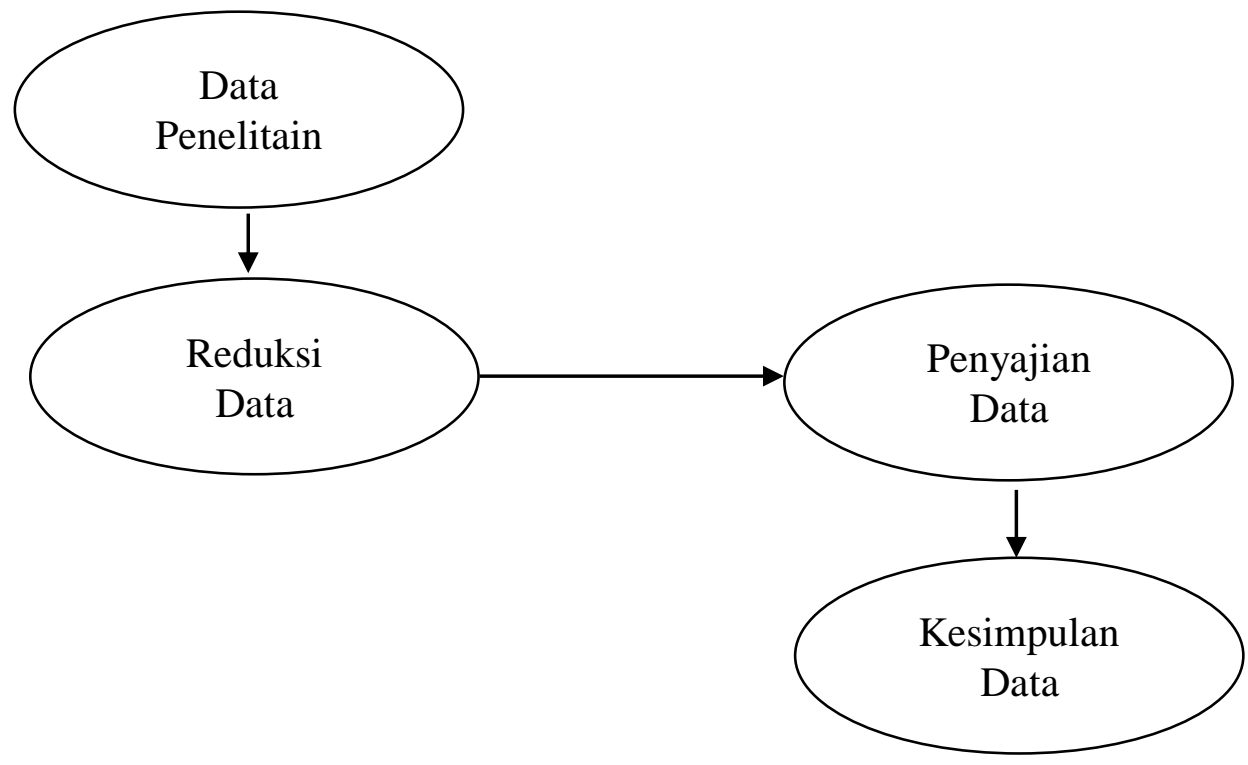


Gambar 1. Tahap-tahap penelitian menurut Matthew Miles dan A. Michael Huberman 2002

Berdasarkan langkah-langkah penelitian di atas, maka dapat diuraikan sebagai berikut:

\section{Tahap Reduksi Data (Data Reducation)}

Mereduksi data berarti merangkum, memilih hal-hal yang pokok, memfokuskan pada hal-hal yang penting, dicari tema dan polanya. Dengan demikian data yang telah direduksi akan memberikan gambaran yang lebih jelas dan mempermudah peneliti untuk melakukan mengumpulkan data selanjutnya, dan mencarinya bila diperlukan. Reduksi data dapat dibantu dengan peralatan elektronik seperti komputer mini dengan memberikan kode pada aspek-aspek tertentu.

\section{Pengajian Data (Data Display)}

Dengan mendisplaykan data maka, akan memudahkan untuk memahami apa yang terjadi, merencanakan kerja selanjutnya berdasarkan apa yang telah dipahami. Selanjutnya disarankan, dalam melakukan display data, selain dengan teks yang negatif, juga dapat berupa grafik, matrik, network (internet). Untuk itu maka peneliti harus selalu menguji apa yang telah ditemukan pada saat memasuki lapangan yang masih bersifat hipotetik itu berkembang atau tidak.

\section{Kesimpulan Data (Verification)}

Kesimpulan awal yang dikemukakan masih bersifat sementara, dan akan berubah bila ditemukan bukti-bukti yang kuat yang mendukung pada tahap pengumpulan data berikutnya. Tetapi apabila kesimpulan yang dikemukakan pada tahap awal, didukung oleh bukti yang valid dan konsisten saat peneliti kembali ke lapangan mengumpulkan data, maka kesimpulan yang dikemukakan merupakan kesimpulan yang kredibel (Matthew Miles dan A. Michael Huberman, 2002).

\section{HASIL}

\section{A. Peran Guru PAl Dalam Membentuk Karakter Peserta Didik Kelas VII SMP Muhammadiyah Ambon}

\section{Peranan Guru Pendidikan Agama Islam}

Peranan guru pendidikan agama Islam sangatlah penting untuk membentuk karakter peserta didik, hal ini dikarenakan Guru Pendidikan Agama Islam adalah guru yang dapat bertanggung jawab membentuk karakter peserta didik dengan ilmu, iman dan ketaqwaanya. Guru Pendidikan Agama Islam sudah mempelajari ilmu yang dapat menjaga dirinya di dunia dan di akhirat dengan syariat Islam. Berdasarkan hasil penelitian yang dilakukan oleh peneliti dengan melakukan wawancara, observasi, dan dokumentasi mengenai Peranan Guru Pendidikan Agama Islam Dalam Pembentukan Karakter Peserta didik Kelas VII SMP Muhammadiyah Ambon. Peneliti akan memaparkan Peranan Guru 
Pendidikan Agama Islam dalam pembentukan karakter peserta didik kelas VII SMP Muhammadiyah Ambon yaitu sebagai berikut:

\section{a. Guru sebagai Pengajar}

Berdasarkan wawancara dengan kepala sekolah, Bapak Ardon Jamdin, M.Pd. yaitu apakah Guru Pendidikan Agama Islam telah mengajarkan materi dengan baik khususnya dalam pembentukan karakter yaitu mengajarkan tentang kejujuran, kedisiplinan, sopan-santun, dan keteladanan kepada peserta didiknya? Beliau mengatakan bahwa:

"Untuk Guru Pendidikan Agama Islam, khususnya di SMP Muhammadiyah Ambon, mereka telah memberikan pengajaran yang baik, khususnya dalam pembentukan karakter. Mereka juga telah mengajarkan tentang kejujuran, kedisiplinan, sopan-santun, dan keteladanan kepada peserta didiknya. Salah satu contoh yang tidak langsung yang dilakukan Guru Pendidikan Agama Islam yaitu dengan selalu datang tepat waktu hal tersebut secara tidak langsung mengajarkan peserta didik untuk disiplin".

Sebagaimana pernyataan Guru Pendidikan Agama Islam itu sendiri yaitu Ibu Parmi Madi, S.Pd.I. yang mengatakan bahwa:

"Dalam proses pembelajaran seorang guru tidak hanya menyampaikan materi pelajaran saja, tetapi juga mengajarkan kepada peserta didik untuk berperilaku yang baik. Yaitu dengan memberikan pembelajaran tentang kejujuran, kedisiplinan, sopansantun, dan keteladanan kepada peserta didik. Seorang guru juga harus memberikan contoh yang baik kepada peserta didiknya, misalnya dengan selalu datang tepat waktu, hal tersebut bisa memberikan contoh kepada peserta didik untuk berperilaku disiplin".

Berdasarkan jawaban kepala sekolah dan guru PAI tersebut memiliki jawaban yang sama, yakni Guru Pendidikan Agama Islam telah mengajarkan tentang kejujuran, kedisiplinan, sopan-santun, dan keteladanan kepada peserta didik kelas VII SMP Muhammadiyah Ambon. Untuk mencapai tujuan-tujuan itu maka guru perlu memahami sedalamdalamnya pengetahuan yang akan menjadi tanggung jawabnya dan menguasai dengan baik metode dan teknik mengajar, khusus nya dalam pembentukan karakter peserta didik.

\section{b. Guru sebagai Pembimbing}

Berdasarkan hasil wawancara terhadap kepala sekolah yaitu bagaimana Guru Pendidikan Agama Islam dalam membimbing peserta didik untuk berperilaku jujur, disiplin, sopan-santun dan teladan? Beliau mengatakan bahwa:

"Guru Pendidikan Agama Islam berkewajiban untuk membimbing, peserta didiknya supaya berkarakter yang baik, dengan memberikan contoh teladan yang baik sesuai syari'at Islam seperti salah satunya membimbing peserta didik untuk melaksanakan 
Shalat Dhuhur berjama'ah di sekolah" (Wawancara. Ardon Jamdin, 2020).

Sebagaimana ungkapan Guru Pendidikan Agama Islam itu sendiri yaitu:

"Sudah tugas kami sebagai seorang Guru Pendidikan Agama Islam membimbing peserta didik-siswi kami, yaitu dengan memberikan solusi dan bimbingan berupa kejujuran, kedisiplinan, sopan-santun, dan keteladanan. Misalnya dengan memberikan bimbingan kepada peserta didik yang nakal dengan pendekatan-pendekatan yang lebih dan memberikan arahan kepada anak tersebut untuk berperilaku yang lebih baik lagi. Kami sebagai Guru Pendidikan Agama Islam dalam membimbing peserta didik kami tidak dengan kekerasan tetapi menggunakan pendekatan supaya anak sedikit lebih menurut dan tidak membangkang" (Wawancara. Parmi Madi, 2020).

Berdasarkan wawancara yang penulis lakukan di atas dapat dimaknai bahwa Guru Pendidikan Agama Islam sudah menjadi peran yang baik dan telah menjalankan tugasnya secara maksimal. Guru Pendidikan Agama Islam telah memberikan bimbingan yang baik terhadap peserta didiknya.

\section{c. Guru sebagai Pemimpin}

Berdasarkan hasil wawancara dengan kepala sekolah yaitu, bagaimana Guru Pendidikan Agama Islam dalam mengatur dan merencanakan agar peserta didik agar bisa berperilaku jujur, disiplin, sopan-santun, dan teladan, serta bagaimana Guru Pendidikan Agama Islam menilai dan mengontrol bahwa rencana itu terlaksana dengan baik?, beliau mengatakan:

"Guru Pendidikan Agama Islam dalam mengatur peserta didik untuk berperilaku yang jujur, disiplin, sopan-santun, dan teladan sebenarnya susah-susah gampang karena anak-anak tersebut memiliki karakter yang berbeda-beda. Terlebih untuk peserta didik yang susah di atur, biasanya Guru Pendidikan Agama Islam untuk mengatasi hal tersebut yaitu komunikasi dengan baik kepada anak tersebut supaya anaknya juga mau menurut ketika diberikan arahan. Dan untuk merencanakan supaya anak bisa berperilaku yang jujur, disiplin, sopan-santun, dan teladan Guru Pendidikan Agama Islam menggunakan strategi tersendiri agar anak itu bisa menurut. Untuk menilai dan mengontrol bahwa rencana Yang Guru Pendidikan Agama Islam dalam membentuk karakter peserta didik itu terlaksana dengan baik adalah dengan melihat absen harian peserta didik. Disitu akan terlihat peserta didik yang tidak hadir dan alpa atau tidak ada keterangan" (Wawancara. Ardon Jamdin, 2020). 
Hal ini dikuatkan dengan pernyataan Guru Pendidikan Agama Islam itu sendiri yaitu sebagai berikut:

"Dalam mengatur agar peserta didik untuk berperilaku jujur, disiplin, sopan-santun, dan teladan tidaklah mudah dengan karakter yang dimiliki setiap anak berbeda-beda. Untuk mengaturnya misalnya dengan pembiasaan-pembiasaan. Seperti membiasakan berdoa sebelum di mulainya pelajaran akan mengajarkan anak untuk berperilaku disiplin dan teladan, membiasakan bersalaman ketika akan masuk kelas dan setelah pelajaran berakhir mengajarkan anak untuk sopan santun, dan membiasakan anak untuk tidak mencontek mengajarkan anak untuk berperilaku jujur. Dan untuk merencanakan supaya anak bisa berperilaku jujur, disiplin, sopansantun, dan teladan yaitu dengan strategi-strategi khusus. Misalnya dengan mengamati setiap karakter peserta didik, komunikasi dengan baik kepada peserta didik, dekati peserta didik, dan konsultasi terhadap orangtua. Dan untuk menilai dan mengontrol bahwa rencana itu terlaksana dengan baik adalah dengan melihat absen. Dari melihat absen bisa dilihat mana peserta didik yang rajin dan peserta didik yang sering alpa. Terkadang ketika ada peserta didik yang tidak berangkat tanpa keterangan guru menanyakan kepada teman sekelasnya" (Wawancara. Parmi Madi, 2020).

Berdasarkan pernyataan di atas, maka dapat dimaknai bahwa Guru Pendidikan Agama Islam sudah melakukan dengan baik dalam mengatur dan merencanakan agar peserta didik mempunyai sikap jujur, disiplin, sopan-santun, dan teladan serta menilai dan mengontrol dengan baik bahwa rencana yang dilakukannya bisa terlaksana dengan baik. Namun terkadang apa yang sudah di rencanakan tidak berjalan dengan baik. Karena untuk membentuk agar peserta didik memiliki karakter yang baik itu tidaklah mudah. Setiap peserta didik memiliki karakter yang berbedabeda, apalagi pergaulan di luar sekolah Guru Pendidikan Agama Islam tidak dapat memantau. Karena kapasitas Guru Pendidikan Agama Islam hanyalah di dalam sekolah. Selebihnya pergaulan di luar sekolah itu sudah bukan tanggung jawab Guru Pendidikan Agama Islam lagi tetapi sudah tanggung jawab orangtua dan masyarakat. untuk itu sesuai dengan misi sekolah yaitu "meningkatkan hubungan yang harmonis dengan orangtua murid dan masyarakat untuk mendukung program sekolah.

\section{d. Guru sebagai IImuan}

Berdasarkan hasil wawancara dengan kepala sekolah yaitu: apakah Guru Pendidikan Agama Islam mengikuti perkembangan teknologi untuk membentuk anak agar berperilaku yang berkarakter, dan apakah peserta didik boleh membawa HP didalam kelas selagi untuk kepentingan pembelajaran? Beliau mengatakan bahwa:

"Mengenai perkembangan teknologi yang pada saat ini berkembang secara pesat, sebagai Guru Pendidikan Agama Islam tentunya selalu mengikuti perkembangannya dalam memberikan 
pembelajaran kepada anak didiknya. Misalnya dengan memberikan tugas untuk mencari kisah-kisah Rashul dengan browsing atau dengan mencari melalui buku-buku jika memang ada. Dan untuk masalah apakah peserta didik boleh membawa HP di dalam kelas selagi untuk kepentingan proses pembelajaran dari pihak sekolah tidak mengijinkan peserta didik membawa HP didalam kelas. Karena hal itu bisa membuat anak nantinya akan terganggu di dalam proses pembelajarannya" (Wawancara. Ardon Jamdin, 2020).

Menanggapi pernyataan dari kepala sekolah dan Guru BP hal yang sama juga di ungkapkan oleh Guru Pendidikan Agama Islam, beliau mengatakan bahwa:

"Menjadi seorang Guru Pendidikan Agama Islam tentunya harus mengikuti perkembangan teknologi yang berkembang saat ini, tidak hanya Guru Pendidikan Agama Islam saja tetapi guru-guru yang lainnya juga harus mengikuti perkembangan teknologi untuk kepentingan pembelajaran. Misalnya untuk pemberian tugas biasanya untuk mencari kisah-kisah Rasul, atau mencari artikel tentang agama Islam peserta didik disuruh mencari melalui mediamedia yang lainnya. Seperti melalui buku-buku di perpus tetapi jika buku di perpus tidak ada peserta didik boleh browsing melalui internet. Dan untuk pertanyaan apakah peserta didik boleh membawa HP didalam kelas memang dari pihak sekolah tidak mengijinkan dengan alasan akan mengganggu proses pembelajaran didalam kelas. Tetapi peserta didik boleh browsing melalui HP di luar kelas ketika ada materi yang tidak ada di buku. Dengan dilarangnya peserta didik untuk tidak membawa HP didalam kelas itu akan mengajarkan akan kedisiplinan di sekolah dan didalam kelas" (Wawancara. Parmi Madi, 2020).

Berdasarkan hasil wawancara di atas maka dapat dimaknai bahwa Guru Pendidikan Agama Islam mengikuti perkembangan teknologi yang berkembang untuk menunjang proses pembelajaran dan pembentukan karakter. Peserta didik juga dilarang untuk membawa HP didalam kelas karena hal itu akan mempengaruhi proses pembelajaran di dalam kelas. Hal tersebut juga akan mengajarkan anak bersikap disiplin dengan mematuhi peraturan tersebut.

\section{e. Guru sebagai Pribadi yang Baik}

Berdasarkan wawancara kepada kepala sekolah yaitu apakah Guru Pendidikan Agama Islam menjelaskan pembelajaran dengan diselangi dengan humoran agar peserta didik tidak merasa bosan didalam kelas khususnya dalam menjelaskan tentang pendidikan karakter? Beliau mengatakan bahwa:

"Guru Pendidikan Agama Islam dalam menjelaskan materi didalam kelas menggunakan humoran yang mendidik, maksudnya ketika menjelaskan materi didepan kelas humorannya tidak keluar dari 
materi pembelajaran yang dijelaskan. Dengan begitu peserta didik tidak merasa bosan dan tegang ketika didalam kelas" (Wawancara. Ardon Jamdin, 2020).

Hal tersebut juga dikuatkan dengan pernyataan Guru Pendidikan Agama Islam, yang mengatakan bahwa:

"Di dalam menjelaskan materi atau dalam membentuk karakter peserta didik terkadang menggunakan candaan atau humoran yang mendidik, yaitu maksudnya adalah ketika bercanda itu tidak menyimpang dari materi pembelajaran, dengan begitu peserta didik akan mudah memahami materi dan tidak merasa bosan ketika sedang belajar didalam kelas" (Wawancara. Parmi Madi, 2020).

Berdasarkan wawancara di atas, dapat dimaknai bahwa guru sebagai pribadi yang baik sudah memberikan peranan yang baik bagi anak muridnya. Guru Pendidikan Agama Islam telah menjalankan tugasnya dengan baik mampu menjadi tauladan bagi anak muridnya. Dengan bersikap yang tidak kaku didalam kelas merupakan salah satu ciri bahwa guru bahwa Guru Pendidikan Agama Islam dapat mencairkan suasana didalam kelas agar tidak tegang dengan candaan nya yang mendidik dan tidak menyimpang dari materi yang diajarkannya.

\section{f. Guru sebagai Penghubung}

Berdasarkan wawancara dengan kepala sekolah yaitu Bapak Ardon Jamdin, M.Pd yaitu ketika ada peserta didik yang bermasalah di sekolah apakah Guru Pendidikan Agama Islam mendatang rumah orangtua peserta didik tersebut untuk memberikan arahan kepada orangtuanya agar anaknya berperilaku yang berkarakter, dan apakah Guru Pendidikan Agama Islam bekerja sama dengan masyarakat ketika ada peserta didik yang membolos untuk segera melaporkan ke pihak sekolah?, beliau mengatakan bahwa:

"Ketika ada peserta didik yang bermasalah di sekolah Guru Pendidikan Agama Islam tidak langsung mendatangi rumah orangtua peserta didiknya, tetapi melewati beberapa prosedur. Yaitu yang pertama adalah memberikan arahan kepada peserta didik yang bermasalah, kemudian yang kedua jika tidak berhasil Guru Pendidikan Agama Islam akan melaporkan ke wali kelas, untuk selanjutnya wali kelas akan melaporkan ke guru BK, dari guru BK nantinya akan di tindak lanjut ke orangtua peserta didik. Tetapi dari pihak sekolah tidak datang kerumah orangtua peserta didik yang bermasalah melainkan akan diberikan surat panggilan untuk orangtua peserta didik yang bermasalah untuk datang ke sekolah. Dan untuk apakah Guru Pendidikan Agama Islam bekerja sama dengan masyarakat ketika ada peserta didik yang membolos untuk segera melaporkan kepihak sekolah. Dari pihak sekolah tidak memberikan himbauan kepada Guru Pendidikan Agama Islam saja melainkan kepada guru-guru yang lainnya untuk memberitahu 
kepada masyarakat bahwa ketika masyarakat melihat peserta didik kami sedang berkeliaran di luar sekolah pada saat jam pelajaran maka hendak segera melaporkan ke pihak sekolah" (Wawancara. Ardon Jamdin, 2020).

Hal ini juga dikuatkan oleh pernyataan dari Guru Pendidikan Agama Islam tersebut, beliau mengatakan bahwa:

"Untuk mengenai peserta didik yang bermasalah di sekolah Guru Pendidikan Agama Islam tidak datang ke rumah orangtua peserta didik tersebut. Tetapi Guru Pendidikan Agama Islam wajib melaporkan ke wali kelas ketika ada peserta didiknya yang bermasalah di sekolah untuk nantinya dari wali kelas akan di laporkan kepada guru BP. Dan dari guru BP nantinya akan ditindak lanjut pemanggilan orangtua murid untuk datang ke sekolahan. Jadi bukan Guru Pendidikan Agama Islam yang datang kerumah orangtua murid yang bermasalah melainkan orangtua murid yang dipanggil untuk datang ke sekolah tentunya dengan surat pemanggilan dari pihak sekolah. Guru Pendidikan Agama Islam juga bekerjasama dengan masyarakat, ketika ada peserta didik yang membolos atau berkeliaran di luar sekolah di saat jam pelajaran masyarakat untuk segera melaporkan ke Guru Pendidikan Agama Islam. Tetapi tidak hanya melaporkan ke Guru Pendidikan Agama Islam saja tetapi kepada guru-guru yang lainnya yang nantinya akan dilaporkan ke pihak sekolah" (Wawancara. Parmi Madi, 2020).

Berdasarkan wawancara di atas dapat dimaknai bahwa, Guru Pendidikan Agama Islam sudah berperan dalam pembentukan karakter peserta didik. Yakni dengan melakukan pemanggilan kepada orangtua murid yang bermasalah di sekolah yang tentunya di bantu oleh wali kelas dan guru BK. Guru Pendidikan Agama Islam dan pihak sekolah juga bekerjasama dengan masyarakat, ketika ada peserta didik SMP Muhammadiyah Ambon yang membolos atau berada di luar sekolah ketika jam pelajaran berlangsung untuk bisa melaporkan kepada pihak sekolah. Hal tersebut juga sesuai dengan visi dari SMP Muhammadiyah Ambon yaitu meningkatkan hubungan yang harmonis dengan orangtua murid dan masyarakat untuk mendukung program sekolah.

\section{g. Guru sebagai Pembaharu}

Berdasarkan wawancara dengan kepala sekolah yaitu bapak Ardon Jamdin, M.Pd. yaitu seiring perkembangan zaman yang modern dan teknologi komunikasi misalnya HP, TV, sosial media, dan lain sebagainya. Apakah Guru Pendidikan Agama Islam memberikan arahan kepada peserta didik agar selalu menggunakan teknologi informasi dengan baik dan benar serta memberikan pengetahuan tentang dampak positif dan negatif dalam menggunakan teknologi yang sedang berkembang saat ini? Beliau mengatakan bahwa: 
"Guru Pendidikan Agama Islam mengikuti perkembangan teknologi yang berkembang saat ini karena hal tersebut juga salah satu penunjang untuk proses pembelajaran. Guru Pendidikan Agama Islam tentunya akan memberikan arahan kepada peserta didiknya agar selalu menggunakan teknologi informasi dengan baik dan benar serta memberikan nasehat positif maupun negatif dalam bersosial media".

Hal ini juga dikuatkan oleh pernyataan dari Guru Pendidikan Agama Islam tersebut, beliau mengatakan bahwa:

"Seiring perkembangan teknologi yang berkembang saat ini guru tentunya juga harus mengikuti perkembangan teknologi yang sedang berkembang. karena hal tersebut juga bisa sebagai penunjang untuk proses pembelajaran atau untuk pembentukan karakter peserta didik. Misalnya dengan memberikan tugas untuk mencari materi tentang kisah-kisah Rasul dengan browsing melalui internet atau HP. Tetapi Guru Pendidikan Agama Islam juga harus memberikan arahan kepada peserta didik dalam menggunakan teknologi yang berkembang saat ini. Yakni memberikan nasehat positif maupun negatif dalam menggunakan teknologi informasi" (Wawancara. Parmi Madi, 2020).

Berdasarkan wawancara di atas dapat dimaknai bahwa, Guru Pendidikan Agama Islam juga sebagai pembaharu yakni dengan mengikuti perkembangan teknologi yang berkembang saat ini sebagai salah satu penunjang proses pembelajaran. Guru Pendidikan Agama Islam juga selalu menasehati peserta didik nya ketika menggunakan teknologi informasi seperti HP dan internet, serta memberikan pengetahuan tentang dampak positif dan negatif dalam menggunakan teknologi yang sedang berkembang pada saat ini.

\section{h. Guru sebagai perancang Strategi atau Metode}

Berdasarkan wawancara dengan kepala sekolah yaitu Bapak Ardon Jamdin, M.Pd yaitu: Ketika peserta didik bersikap yang kurang berkarakter misalnya tidak disiplin, kurangnya dalam bersopan-santun, kurang teladan, dan tidak jujur, strategi atau metode apakah yang Guru Pendidikan Agama Islam gunakan dalam pembentukan karakter peserta didik?, maka demikianlah jawaban yang mengatakan:

"Ketika ada peserta didik yang bersikap kurang berkarakter misalnya tidak disiplin, kurang sopan, tidak jujur, dan kurang teladan biasanya Guru Pendidikan Agama Islam mempunyai strategi atau metode tersendiri. Tetapi ketika ada peserta didik yang bermasalah di sekolah tentunya Guru Pendidikan Agama Islam melakukan peneguran terhadap peserta didik, lalu melakukan pembimbingan, jika dengan bimbingan tidak berhasil maka akan di laporkan ke wali kelas untuk di tindak lanjut ke guru BK, dari guru BK akan di lakukan pemanggilan kepada orangtua murid. Selain itu, guru Pendidikan Agama Islam sudah menggunakan strategi 
atau metode pembentukan dengan baik dengan benar dan sudah dilakukan dengan maksimal untuk membentuk karakter peserta didik yang lebih baik lagi".

Peneliti juga menanyakan hal yang sama kepada guru Pendidikan Agama Islam yaitu Ibu Parmi Madi, S.Pd.I, dan beliau mengatakan bahwa:

"Sebagai Guru Pendidikan Agama Islam tentunya harus maksimal dalam mengajarkan anak untuk berperilaku yang baik. Dalam pembentukan karakter Guru Pendidikan Agama Islam menggunakan metode pembentukan karakter seperti seperi metode keteladanan, metode pembiasaan, dan metode qishah. Dan guru pendidikan agam Islam juga sudah menggunakan metode tersebur dengan baik dan benar.

Berdasarkan uraiana yang telah dikemukakan oleh informan di atas, maka dapat disimpulkan bahwa guru PAI sebagai pengajar tentunya harus menggunakan metode yang sesuai untuk mewujudkan pembelajaran yang maksimal. Di dalam pembentukan karakter ada beberapa metode yang bisa digunakan untuk membentuk karakter peserta didik. Misalnya seperti metode uswah atau metode keteladanan, metode keteladanan sangat efektif dan efisien untuk pembentukan karakter peserta didik dimana peserta didik dapat mencontoh perilaku dari gurunya. Misal nya Guru Pendidikan Agama Islam selalu datang tepat waktu, hal tersebut bisa mengajarkan peserta didik untuk teladan. Dan masih banyak lagi metodemetode dalam pembentukan karakter.

\section{Pembentukan Karakter Peserta Didik Kelas VII SMP Muhammadiyah Ambon}

Berdasarkan uraian yang berkaitan dengan 18 indikator keberhasilan pendidikan karakter, maka yang menjadi fokus pada indikator nilai karakter yakni; religius, jujur, disiplin, tanggung jawab dan mandiri yang dilakukan oleh guru PAI di SMP Muhammadiyah Ambon dalam pembentukan karakter peserta didik. Adapun nilai karakter yang dikembangkan di sekolaht erkait dengan pendidikan karakter dapat dilihat sebagai berikut:

\section{a. Nilai Religius}

Nilai religius adalah nilai karakter dalam hubungan Tuhan Yang Maha Esa. Dimana nilai religius berkaitan dengan pikiran, perkataan, dan tindakan yang diupayakan selalu berdasarkan nilai-nilai ketuhan dan ajaran agamanya. Berdasarkan wawancara yang peneliti lakukan di atas, maka peneliti memperoleh jawaban sebagai berikut:

"Iya, peserta didik kelas VII SMP Muhammadiyah Ambon dan seluruh peserta didik di sekolah sebagian besar mengikuti shalat Dzuhur berjama'ah di sekolah karena itu hukumnya wajib, namun sekarang berhubungn peserta didik tidak tatap muka di sekolah dikarenakan pandemi covid 19, maka kewajiban untuk melaksanakan ibadah sholat dan ibadah lainnya tetap dan harus 
dikerjakan bila bersifat wajib di rumah. Begitu juga dengan berjabat tangan dengan guru ketika sebelum dan sesudah jam pelajaran. Bukan hanya ketika di dalam kelas saja peserta didik di ajarkan untuk berjabat tangan kepada guru tetapi ketika berpapasan dengan guru peserta didik juga di ajarkan untuk berjabat tangan. Tetapi kembali lagi kepada karakter masing-masing dari peserta didik itu sendiri. Ada peserta didik yang memang melakukan hal tersebut ada juga yang cuek ketika berpapasan dengan guru ketika di luar kelas. Dan ketika sebelum dan sesudah jam pelajaran peserta didik juga di bimbing untuk melakukan doa sebelum pelajaran di mulai dan setelah jam pelajaran berakhir" (Wawancara. Ardon Jamdin, 2020).

Peneliti juga menanyakan hal yang sama kepada guru Pendidikan Agama Islam yaitu Ibu Parmi Madi, S.Pd.I, dan beliau mengatakan bahwa: "Sebagian besar peserta didik di SMP Muhammadiyah Ambon khususnya untuk kelas VII memiliki nilai religius yang cukup baik, seperti mengikuti shalat dzuhur berjama'ah di sekolah, berjabat tangan dengan guru, dan membaca doa sebelum dan sesudah jam pelajaran. Namun ada sebagian kecil peserta didik yang memang tidak mengikuti aturan yang telah diberikan oleh guru. Itu disebabkan dari faktor intern atau diri sendiri yaitu malas ataupun faktor ekstern yaitu faktor yang mempengaruhi dari luar seperti pergaulan dengan teman-temannya dan faktor dari luar sekolah yang kurang baik.

Berdasarkan wawancara yang peneliti lakukan di atas, maka dapat dimaknai bahwa peserta didik kelas VII SMP Muhammadiyah Ambon sebagian besar memiliki nilai religius yang baik, seperti Shalat Dzuhur berjama'ah di sekolah, berjabat tangan dengan guru, dan membaca doa sebelum dan sesudah proses pembelajaran.

\section{b. Nilai Jujur}

Dalam kurikulum 2013 menganjurkan penanaman sikap jujur, karena dengan adanya penanaman akhlak sejak dini akan dapat tumbuh menjadi kebiasaan dan melekat sebagai karakter peserta didik. Nilai jujur merupakan perilaku yang didasarkan pada upaya menjadikan dirinya sebagai orang yang selalu dapat dipercaya dalam perkataan, tindakan dan pekerjaan baik terhadap diri sendiri maupun orang lain. Salah satu dari nilai kejujuran bisa dilihat dari sikap kejujuran terhadap gurunya saat mengerjakan soal ataupun pekerjaan rumah (PR) nya di rumah atau di sekolah. Berdasarkan wawancara yang peneliti lakukan di atas, maka peneliti memperoleh jawaban sebagai berikut:

"Pembentukan karakter haruslah disertai dengan penanaman akhlak yang baik sesuai dengan tuntunan syari'at Islam terutama sikap jujur, itu merupakan modal utama untuk mendapat kepercayaan dari teman, orangtua, guru, dan masyarakat, peserta 
didik kelas VII di SMP Muhammadiyah Ambon sebagian besar mengerjakan PR di rumah, hanya ada sebagian yang tidak mengerjakan di rumah karena disebabkan faktor dari peserta didik tersebut, seperti malas atau lupa jika ada PR, biasa peserta didik laki-laki yang jarang mengerjakan PR di rumah apalagi di masa pandemi covid 19 seperti sekarang ini. Mereka juga selalu mengerjakan soal ulangan dengan jujur karena ada guru yang mengawasi" (Wawancara. Ardon Jamdin, 2020).

Hal senada juga di ungkapkan oleh guru Pendidikan Agama Islam kelas VII Islam yaitu:

"Sebagian besar pada mata pelajaran Pendidikan Agama Islam peserta didik kelas VII mengerjakan soal dengan jujur walaupun ada beberapa peserta didik memang terkadang ketahuan mencontek teman yang lain atau membuat contekan sendiri. Dan untuk mengerjakan PR sebagian besar peserta didik kelas VII mengerjakan di rumah tetapi ada juga yang mengerjakan di sekolah" (Wawancara. Parmi Madi, 2020).

Berdasarkan hasil wawancara di atas, maka dapat dimaknai bahwa penanaman nilai jujur sangat aktif untuk membentuk karakter peserta didik. Dengan adanya pemberian bimbingan sikap jujur maka akan dapat menjadi kebiasaan dan berubah menjadi suatu karakter dari diri pribadi peserta didik itu sendiri.

\section{c. Nilai Disiplin}

Nilai disiplin merupakan salah satu tata tertib yang ada di SMP Muhammadiyah Ambon. Kedisiplinan juga merupakan suatu tindakan yang menunjukan perilaku tertib dan patuh pada berbagai ketentuan dan peraturan. Disiplin pada saat proses pembelajaran maupun disiplin waktu saat berangkat sekolah, dan lain sebagainya. Kedisiplinan guru dan para peserta didik di SMP Muhammadiyah Ambon cukup baik dan berjalan dengan maksimal. Berdasarkan ungkapan kepala sekolah yang mengatakan bahwa:

"Seorang guru harus memberikan tauladan yang baik pada peserta didiknya. Oleh karena itu, menjadi seorang guru jangan sampai menyepelekan kedisiplinan waktu. Idiealnya sebelum guru memerintahkan peserta didiknya untuk disiplin, seorang guru harus terlebih dahulu memberikan contoh kepada peserta didiknya yaitu dengan selalu datang tepat waktu juga. Peserta didik di SMP Muhammadiyah Ambon selalu datang tepat waktu dan berpakaian rapi karena hal tersebut merupakan peraturan yang harus dipatuhi semua peserta didik SMP Muhammadiyah Ambon tidak hanya kelas VII saja. Walaupun ada beberapa peserta didik yang memang terkadang tidak mematuhi tata tertib tersebut, dan jika ada peserta didik yang tidak mematuhi tata tertib sekolah guru pun wajib 
menegur nya dengan baik dengan baik-baik" (Wawancara. Ardon Jamdin, 2020).

Hal senada juga diungkapkan oleh Guru Pendidikan Agama Islam kelas VII yang mengatakan bahwa:

"Peserta didik kelas VII SMP Muhammadiyah Ambon sudah menerapkan nilai kedisiplinan, karena disiplin itu sendiri termasuk dari peraturan sekolah jika melanggar peraturan tersebut maka akan mendapat sangsi dan teguran dari guru, oleh karena itu mereka selalu datang tepat waktu dan berpakaian rapi. Hanya saja ada sebagian kecil yang masih melanggarnya" (Wawancara. Parmi Madi, 2020).

Berdasarkan wawancara di atas, maka dapat dimaknai bahwa guru merupakan tombak keberhasilan dalam pembelajaran, guru juga merupakan model di dalam kelas untuk peserta didiknya, khususnya Guru Pendidikan Agama Islam. Untuk itu seorang Guru Pendidikan Agama Islam harus dapat memberikan contoh yang baik kepada peserta didiknya baik dari segi ucapan maupun tindakan seperti halnya nilai kedisiplinan. Maka dapat dilihat nilai karakter kedisiplinan di SMP Muhammadiyah Ambon.

\section{d. Nilai Tanggung Jawab}

Nilai tanggung jawab yaitu merupakan sikap dan perilaku seseorang untuk melaksanakan tugas dan kewajibannya sebagaimana yang telah dia lakukan. Bertanggung jawab saat mengerjakan tugas-tugas sekolah, tanggung jawab menjaga kebersihan sekolah, serta tanggung jawab menjaga nama baik sekolah SMP Muhammadiyah Ambon.

Berdasarkan wawancara yang peneliti lakukan dengan pertanyaan yaitu apakah peserta didik kelas VII memiliki nilai tanggung jawab terhadap peraturan yang ada di sekolah serta bertanggung jawab terhadap tugas-tugas sekolahnya, maka kepala sekolah mengatakan bahwa:

"Peserta didik di SMP Muhammadiyah Ambon sudah mematuhi peraturan yang ada di sekolah dengan baik, hanya sebagian kecil peserta didik yang masih sulit untuk di atur, dan belum memenuhi peraturan yang telah di berikan" (Wawancara. Ardon Jamdin, 2020).

Sebagaimana ungkapan Guru Pendidikan Agama Islam yang mengatakan bahwa:

"Sebagian besar peserta didik di SMP Muhammadiyah Ambon sudah memiliki tanggung jawab yang tinggi khususnya untuk kelas VII, hal ini dapat dibuktikan dengan mereka yang bisa menjaga nama baik sekolah SMP Muhammadiyah Ambon, selain itu juga peserta didik kelas VII sudah mengerjakan tugas-tugas sekolah dengan baik, misalnya tugas dalam menjaga kebersihan sekolah. 
Yaitu dengan mengerjakan piket bersama setiap harinya dan itu sudah di jadwal. Mereka biasa nya membagi tugas nya masingmasing, hal tersebut juga mengajarkan anak untuk saling bergotong royong" (Wawancara. Parmi Madi, 2020).

Berdasarkan hasil wawancara di atas, maka dapat dimaknai bahwa pemberian nilai tanggung jawab kepada peserta didik dalam hal sikap tanggung jawab sangat dibutuhkan untuk bersikap amanah terhadap tugas yang telah diberikan serta menjaga nama baik sekolah dan tidak melanggar aturan-aturan yang ada di SMP Muhammadiyah Ambon walaupun ada beberapa peserta didik yang memang terkadang masih melanggar peraturan sekolah.

\section{e. Nilai Kemandirian}

Nilai mandiri yaitu suatu sikap dan perilaku yang tidak mudah tergantung pada orang lain dalam menyelesaikan tugas-tugas. Peserta didik kelas VII memiliki kemandirian dalam belajar, hanya ada sebagian kecil yang memang masih perlu bantuan dari guru. Berdasarkan wawancara yang peneliti lakukan dengan kepala sekolah terkait dengan peserta didik memiliki kemandirian dalam belajar. Berdasarkan hasil wawancara tersebut, kepala sekolah menuturkan bahwa:

"sejauh yang saya amati, tentunya tidak semua peserta didik memiliki kemandirian, ada sebagian kecil dari mereka yang masih membutuhkan bantuan dari teman ataupun gurunya dalam hal mengerjakan tugas, namun sebagian besar peserta didik telah memiliki nilai kemandirian yang baik" (Wawancara. Ardon Jamdin, 2020).

Hal ini sebagaimana diungkapkan oleh guru PAI kelas VII SMP Muhammadiyah Ambon yang mengatakan bahwa:

"Dalam proses belajar mengajar khususnya dalam mata pelajaran Pendidikan Agama Islam, tidak semua materi yang diberikan oleh guru bisa dipahami peserta didik atau diterima dengan baik, terkadang ada yang belum dimengerti dan belum faham, saya selaku guru PAI selain bertanya terkait pehaman kepada peserta didik juga mengajarkan ulang materi tersebut secara berlahanlahan dan selain itu juga dengan meminta bantuan kepada sesama peserta didik untuk membantuan mengajarkan atau memberikan pehaman kepada peserta didik lainnya karena saya yakini bahwa terkadang peserta didik akan cepat memahami materi bila diajarkan dengan cara yang berbeda-beda salah satu dengan cara penyampaian dari teman sekelasnya" (Wawancara. Parmi Madi, 2020). 
Berdasarkan hasil wawancara di atas, maka dapat dimaknai bahwa peserta didik kelas VII SMP Muhammadiyah Ambon sebagian besar sudah memiliki kemandirian, hanya ada sebagian kecil yang masih membutuhkan bantuan dari teman maupun gurunya. Adapun cara yang dilakukan oleh Guru Pendidikan Agama Islam untuk membentuk karakter peserta didik melalui strategi yaitu menggunakan metode pembiasaan yaitu Guru Pendidikan Agama Islam berperan langsung terhadap pembentukan karakter peserta didik dengan cara memberikan pembiasaan, pemberian motivasi, dan pemberian bimbingan.

\section{B. Faktor Penghambat dan Pendukung Guru PAl Dalam Membentuk Karakter Peserta Didik Kelas VII di SMP Muhammadiyah Ambon}

\section{Faktor penghambat}

Berdasarkan wawancara dengan kepala sekolah yaitu Bapak Ardon Jamdin, M.Pd, terkait dengan faktor penghambat dalam pembentukan karakter peserta didik, maka berkut penuturan informan:

"Dalam pembentukan karakter tentunya ada kendala yang di temui. Yakni diantaranya adalah kurang tanggapnya wali murid ketika ada pemanggilan dari pihak sekolah, latar belakang anak yang kurang baik, dan pergaulan anak yang kurang baik dengan di luar lingkungan sekolah".

Peneliti jug menanyakan hal yang sama kepada Guru Pendidikan Agama Islam yaitu Ibu Parmi Madi, S.Pd.I, dan beliau mengatakan bahwa: "Untuk kendala yang di temui dalam pembentukan karakter yaitu faktor eksternal yaitu faktor dari luar. Yakni seperti pergaulan di luar sekolah yang kurang baik, latar belakang dari keluarga yang broken home dan penyalahgunaan media sosial yang kurang baik akan mempengaruhi peserta didik untuk berperilaku yang kurang baik di sekolah".

Dari pernuturan tersebut, maka dapat disimpulkan bahwa dalam pembentukan karakter tentunya ada kendala yang ditemui. Guru Pendidikan Agama Islam sudah melakukan peranannya dengan cukup baik tetapi pada faktanya apa yang telah direncanakan dengan baik terkadang hasilnya kurang baik. Guru Pendidikan Agama Islam telah mengajarkan dan membimbing peserta didik nya baik di kelas ataupun luar kelas untuk berperilaku jujur, disiplin, sopan santun, dan teladan. Tetapi pergaulan di luar sekolah Guru Pendidikan Agama Islam tidak bisa memantau, seperti pergaulan dengan teman sebaya. Apa lagi pada zaman sekarang teknologi sudah berkembang sangat cepat, misalnya seperti internet dan HP. Dengan internet peserta didik bisa mencari sesuatu dengan mudah, jadi guru pendidikan juga memberikan arahan kepada peserta didik untuk menggunakan media sosial dengan baik dan benar. Hal tersebutlah yang menjadi kendala dalam pembentukan karakter peserta didik.

\section{Faktor Pendukung}


Berdasarkan wawancara dengan kepala sekolah yaitu Bapak Ardon Jamdin, M.Pd, terkait dengan faktor pendukung dalam pembentukan karakter peserta didik, maka beliau mengatakan bahwa:

"Faktor pendukung dalam pembentukan karakter yaitu seperti mengajarkan anak untuk mengaji, kultum, azan, shalat duha dan shalat zuhur berjamaah di sekolah. Dengan mengajarkan anak hal tersebut akan membuat akhlak anak semakin meningkat".

Peneliti jug menanyakan hal yang sama kepada Guru Pendidikan Agama Islam yaitu Ibu Parmi Madi, S.Pd.I, dan beliau mengatakan bahwa: "Sedangkan faktor pendukung dalam pembentukan karakter yaitu seperti faktor eksteren atau faktor yang dipengaruhi dari luar seperti keluarga dan lingkungan yang baik". Pembentukan karakter tidak terlepas dari faktor-faktor yang mendukungnya. Faktor tersebut mencakup faktor internal dan faktor eksternal. Faktor internal berarti faktor-faktor yang berpengaruh terhadap pembentukan karakter dari dalam individu sendiri. Tanpa adanya dorongan yang dapat mengubah individu tersebut dari diri sendiri ke arah yang lebih baik, itupun akan sia-sia. Faktor eksternal yang mempengaruhi pembentukan karakter antara lain dari masyarakat, kebijakan pendidikan, kesepakatan, kurikulum terpadu, pengalaman pembelajaran evaluasi, bantuan orang tua. Adapun faktor internal dan eksternal yang tertera di atas akan berkembang secara baik jika semua pihak mendukung. Tetapi yang menjadi penghambat dalam penanaman pendidikan karakter dalam konteks masyarakat perlu di garis bawahi pengaruh media masa. Alat-alat komunikasi ini setiap hari mengenalkan nilai tertentu yang kadang berlainan dengan nilai yang ditanamkan di sekolah. pengaruh media sehingga seringkali membuat pengaruh sekolah tidak kuat bahkan kalah.

Berdasarkan wawancara di atas, dapat dimaknai bahwa Guru Pendidikan Agama Islam sudah berperan penting dalam pembentukan karakter peserta didik. Dimana Guru Pendidikan Agama Islam juga sebagai sudah melakukan tugasnya dengan baik dan benar untuk membentuk karakter peserta didik agar menjadi lebih baik lagi. Dalam semua proses tersebut tentunya Guru Pendidikan Agama Islam juga dibantu oleh guru-guru yang lainnya.

\section{PEMBAHASAN}

\section{A. Peran guru PAI Dalam Membentuk Karakter Peserta Didik Kelas VII SMP Muhammadiyah Ambon}

Peran adalah perangkat tingkah yang diharapkan dimilki oleh orang yang berkedudukan dalam masyarakat, sedangkan peranan adalah bagian yang dimainkan seseorang pemain, tindakan yang dilakukan oleeh seseorang dalam suatu peristiwa. Peran dalam hal ini adalah peran Guru Pendidikan Agama Islam dalam pembentukan karakter. Peranan pokok guru yaitu mengajar yang mendidik dan mengajar adalah belajar. Peranperan seorang guru mencakup 8 macam, yaitu: (Oemar Hamalik, 2004). 
1. Guru sebagai pengajar yaitu guru bertugas memberikan pengajaran dalam sekolah. Menyampaikan pelajaran agar murid memahami dengan baik semua pengetahuan yang telah disampaikan.

2. Guru sebagai pembimbing yaitu guru berkewajiban memberikan bantuan kepada murid agar mereka mampu menemukan masalahnya sendiri, dan menyesuaikan sendiri dengan lingkungannya.

3. Guru sebagai pemimpin yaitu guru berkewajiban mengadakan supervisi atas kegiatan belajar murid, mengatur disiplin kelas secara demokratis.

4. Guru sebagai ilmuan yaitu guru dipandang sebagai orang paling berpengetahuan, dan bukan saja berkewajiban mengembangkan pengetahuan itu dan terus menerus menumpuk pengetahuan yang telah dimilikinya, akan tetapi guru harus mengikuti dan menyesuaikan diri dengan teknologi yang berkembang secara pesat.

5. Guru sebagai pribadi yaitu harus memiliki sifat-sifat yang disenangi oleh murid-muridnya.

6. Guru sebagai penghubung yaitu guru berfungsi sebagai pelaksana.

7. Guru sebagai pembaharu yaitu pembaharu di masyarakat.

8. Guru sebagai pembangunan yaitu guru baik sebagai pribadi maupun sebagai guru profesional dapat menggunakan setiap kesempatan yang ada untuk membantu berhasilnya pembangunan masyarakat.

Peranan Guru Pendidikan Agama Islam sangatlah penting untuk pembentukan pendidikan karakter peserta didik. Guru sebagai suri tauladan bagi peserta didiknya dalam memberikan contoh karakter yang baik sehingga mencetak generasi yang baik pula. Sebagaimana firman Allah dalam QS. Al-Ahzab (33):21 yang berbunyi:

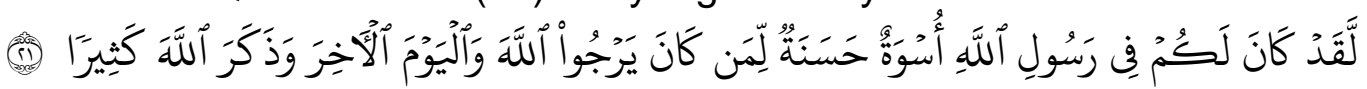

Terjemahnya: "Sesungguhnya telah ada pada (diri) Rasulullah itu suri teladan yang baik bagimu (yaitu) bagi orang yang mengharap (rahmat) Allah dan (kedatangan) hari kiamat dan dia banyak menyebut Allah".

Pendidikan karakter memiliki esensi yang sama dengan pendidikan moral atau akhlak. Dengan penerapan pendidikan karakter faktor yang harus dijadikan sebagai tujuan adalah terbentuknya kepribadian peserta didik supaya menjadi manusia yang baik, dan hal itu sama sekali tidak terikat dengan angka dan nilai. Dengan demikian, dalam konteks pendidikan, pendidikan karakter adalah pendidikan nilai yakni penanaman nilai-nilai luhur yang digali dari budaya bangsa Indonesia (Nurla Isna Aunillah, 2011).

Pakar psikologi mendefinisikan karakter sebagai sifat, watak atau tabiat seseorang yang telah dimiliki sejak lahir dan merupakan sesuatu yang membedakan setiap individu. Karakter biasanya menunjukan kualitas dari mental atau moral seseorang dan menunjukan perbedaan satu individu dengan lainnya (Rosyadi Rahmat, 2013). Oleh karena 
pendidikan karakter adalah pendidikan untuk membentuk kepribadian seseorang melalui pendidikan budi pekerti, yang hasilnya terlihat dalam tindakan nyata seseorang, yaitu tingkah laku yang baik, jujur, bertanggung jawab, menghormati hak orangtua, kerja keras dan sebagainya (Heri Gunawan, 2012).

Berdasarkan pendapat di atas dapat dijelaskan bahwa pendidikan karakter merupakan tingkah laku yang dilandasi dengan sifat yang melekat pada diri peserta didik. Karakter dibentuk oleh pribadi seseorang sesuai dengan perilakunya. Karakter dan akhlaq tidak memiliki perbedaan yang signifikan. Keduanya didefinisikan sebagai suatu tindakan yang terjadi tanpa ada pemikiran lagi karena sudah tertanam dalam pikiran, dengan kata lain, keduanya dapat disebut dengan kebiasaan. Apabila peserta didik berperilaku tidak jujur, tentu orang tersebut telah memanifestasikan perilaku buruk. Sebaliknya, apabila seseorang berperilaku jujur, tentu orang tersebut memanifestasikan perilaku yang mulia. Seseorang berkarakter apabila tingkah lakunya sesuai kaidah moral.

Berdasarkan paparan di atas, maka pengmenbagan pendidikan karakter yang terdapat di SMP MuhammadiyahAmbon untuk lebih memfokuskan kepada 5 nilai-nilai karakter yang telah dijelaskan di atas sebagai indikator pendidikan karakter yang dikembangkan, yaitu:

1. Religius, yaitu sikap dan perilaku yang patuh dalam melaksanakan ajaran agama yang dianutnya.

2. Jujur, yaitu perilaku yang didasarkan pada upaya menjadikan dirinya sebagai orang yang selalu dapat dipercaya dalam perkataan, tindakan dan pekerjaan.

3. Disiplin, yaitu tindakan yang menunjukan perilaku tertib dan patuh pada berbagai ketentuan dan peraturan.

4. Tanggung jawab, yaitu sikap dan perilaku seseorang untuk melaksanakan tugas dan kewajiban.

5. Mandiri, yaitu sikap dan perilaku yang tidak mudah bergantung pada orang lain dalam menyelesaikan tugasnya.

Dengan demikian, maka dalam hubungannya dengan pendidikan, pendidikan karakter dapat dimaknai sebagai pendidikan, nilai, budi pekerti, moral, watak yang bertujuan mengembangkan kemampuan peserta didik untuk menentukan keputusan baik-buruk, memelihara kebaikan, mewujudkan dan menebar kebaikan dalam kehidupan sehari-hari dengan sepenuh hati.

\section{B. Faktor Penghambat dan Pendukung Guru PAl Dalam Membentuk Karakter Peserta Didik Kelas VII di SMP Muhammadiyah Ambon 1. Faktor penghambat}

Pembentukan karakter tidak terlepas dari faktor-faktor yang penghambat. Faktor tersebut mencakup faktor internal dan faktor eksternal. Faktor internal berarti faktor-faktor yang berpengaruh terhadap pembentukan karakter dari dalam individu sendiri. Tanpa adanya dorongan yang dapat mengubah individu tersebut dari diri sendiri ke arah 
yang lebih baik, itupun akan sia-sia. Faktor eksternal yang mempengaruhi pembentukan karakter antara lain dari masyarakat, kebijakan pendidikan, kesepakatan, kurikulum terpadu, pengalaman pembelajaran evaluasi, bantuan orang tua. Adapun faktor internal dan eksternal yang tertera di atas akan berkembang secara baik jika semua pihak mendukung. Tetapi yang menjadi penghambat dalam penanaman pendidikan karakter dalam konteks masyarakat perlu di garis bawahi pengaruh media masa. Alat-alat komunikasi ini setiap hari mengenalkan nilai tertentu yang kadang berlainan dengan nilai yang ditanamkan di sekolah. Begitu besarnya pengaruh media sehingga seringkali membuat pengaruh sekolah tidak kuat bahkan kalah (Dharmma Kusuma, 2011).

Upaya lembaga pendidikan dalam mendidik juga memerlukan dukungan dari institusi media masa seperti televisi, internet, tabloid, koran, dan majalah. Media televisi dapat menyajikan acara-acara tentang potret kehidupan dan prilaku sehari-hari baik dalam bentuk kisah nyata maupun dramatisasi sesuai dengan tujuan yang dikehendaki. Media televisi juga sebagai media massa yang paling populer dan digemari oleh lapisan masyarakat, termasuk anak-anak dan remaja. Media televisi tidak hanya mengajarkan tingkah laku, tetapi juga tindakan sebagai stimulus untuk membangkitkan tingkah laku yang di pelajari dari sumber-sumber lain. Media televisi sesungguhnya memiliki kelebihan dalam membantu tugas guru dan orang tua dalam menanamkan pendidikan karakter terhadap anak secara berkesinambungan (Zubaedi, 2011).

Jadi untuk membentuk karakter yang diharapkan, individu juga harus mempunyai kesadaran akan cepat mengubah dirinya sendiri dan apabila individu yang kurang memiliki kesadaran proses perubahannya akan lama.

\section{Faktor pendukung}

Jika ada faktor penghambat tentunya ada pula faktor pendukung atau faktor yang mempengaruhi keberhasilan dalam pendidikan karakter. Untuk itu penulis akan menjelaskan faktor-faktor yang mempengaruhi keberhasilan pendidikan karakter adalah sebagai berikut:

Pertama, faktor insting (naluri). Aneka corak refleksi sikap, tindakan, dan perbuatan manusia dimotivasi oleh potensi kehendak yang dimotori oleh insting seseorang (dalam bahasa Arab disebut gharizah). Insting merupakan seperangkat tabiat yang dibawa manusia sejak lahir. Para psikolog menjelaskan bahwa insting berfungsi sebagai motivator penggerak yang mendorong lahirnya tingkah laku seperti naluri makan, naluri berjodoh, naluri keibubapakan, naluri berjuangan, dan naluri ber Tuhan. Kedua, faktor yang mempengaruhi keberhasilan pendidikan karakter adalah adat atau kebiasaan. Adat atau kebiasaan adalah setiap tindakan dan perbuatan seseorang yang dilakukan secara berulang-ulang dalam bentuk yang sama sehingga menjadi kebiasaan, seperti pakaian, makan, tidur, dan olahraga. Pada perkembangan selanjutnya suatu perbuatan yang dilakukan berulang-ulang dan telah menjadi kebiasaan, akan dikerjakan dalam waktu singkat, menghemat waktu dan perhatian. 
Ketiga, secara langsung atau tidak langsung keturunan sangat mempengaruhi pembentukan karakter atau sikap seseorang. Sifat-sifat asasi anak merupakan pantulan sifat-sifat asasi orangtuanya. Anak kadang-kadang mewarisi sebagian besar dari salah satu sifat orangtuanya. Keempat, salah satu aspek yang turut memberikan saham dalam terbentuknya corak sikap dan tingkah laku seseorang adalah faktor lingkungan dimana seseorang berada.

Jika penulis cermati dari penjelasan di atas tersebut, sebenarnya ada dua aspek yang menjadi faktor berhasilnya pendidikan karakter. Pertama, membimbing hati nurani peserta didik agar berkembang lebih positif secara bertahap dan berkesinambungan. Hasil yang diharapkan, hati nurani peserta didik akan mengalami perubahan dari semula bercorak egosentris menjadi alturis. Kedua, memupuk, mengembangkan, menanamkan nilai-nilai dan sifat-sifat positif kedalam pribadi peserta didik. Seiring dengan itu, pendidikan budi pekerti juga mengikis dan menjauhkan peserta didik dari sifat-sifat dan nilai-nilai buruk.

Berdasarkan pemaparan di atas tujuan dari pendidikan karakter yaitu untuk menguatkan dan mengembangkan serta mengoreksi nilai-nilai kehidupan yang sangat penting, selain itu untuk menjadikan kepribadian seseorang supaya menjadi lebih baik. Hasil yang diharapkan, ia akan mengalami proses perubahan nilai, transaksi nilai dan transinternalisasi (proses pengorganisasian dan pembiasaan nilai-nilai kebaikan menjadi kepercayaan atau keimanan yang pribadi).

\section{KESIMPULAN}

Berdasarkan hasil penelitian mengenai peranan guru Pendidikan Agama Islam dalam pembentukan karakter peserta didik kelas VII SMP Muhammadiyah Ambon, maka kesimpulan yang dapat ditarik dari penelitian yang dilakukan sebagai berikut:

1. Guru pendidikan agama Islam dalam pembentukan karakter peserta didik kelas VII SMP Muhammadiyah Ambon sudah berperan cukup baik, dimana guru Pendidikan Agama Islam sudah melakukan peranannya seperti guru sebagai pengajar yakni guru Pendidikan Agama Islam telah mengajarkan tentang kejujuran, kedisiplinan, sopan-santun dan keteladanan. Guru sebagai pembimbing yakni guru Pendidikan Agama Islam telah membimbing peserta didik nya untuk berperilaku jujur, disiplin, sopan-santun, dan teladan. Guru sebagai pemimpin yakni guru Pendidikan Agama Islam mengatur peserta didik nya untuk berperilaku yang berkarakter seperi jujur, disiplin, sopansantun, dan tealadan. Guru sebagai ilmuan dimana guru Pendidikana Agama Islam menggunakan media teknologi yang berkembang saat ini untuk mendukung proses pembentukan karakter peserta didik. Peranan guru tersebut terlaksanakan dengan baik seperti yang diharapkan walaupun penerapannya belum maksimal.

2. Faktor penghambat dalam pembentukan karakter peserta didik kelas VII di SMP Muhammadiyah Ambon adalah faktor eksternal seperti pergaulan teman sebaya yang kurang baik dan adanya media sosial 
yang berlebihan dan tanpa bimbingan orangtua. Faktor pendukung dalam pembentukan karakter peserta didik adalah lingkungan sekolah yang selalu mendukung pembentukan karakter peserta didik. Faktor pendukung dalam pembentukan karakter peserta didik kelas VII SMP Muhammadiyah Ambon yaitu dari latar belakang lingkungan keluarga, dimana keluarga akan mengajarkan hal-hal baik terhadap anaknya.

\section{DAFTAR PUSTAKA}

[1] Departemen Agama RI, Al-Qur'an dan Terjemahnya. (Bandung: SYGMA, 2010.

[2] Dharmma Kusuma, Pendidikan Karakter (Kajian Teori dan Praktik di Sekolah), (Bandung: PT Remaja Rosdakarya, 2011.

[3] Heri Gunawan, Pendidikan Karakter Konsep dan Implementasi, (Jakarta: Alfabeta, 2012.

[4] Lexy J. Moleong, Metode Penelitian Kualitatif, (Bandung: PT Remaja Rosda Karya, 2000.

[5] Matthew Miles dan A. Michael Huberman. Analisa data Kualitatif: Buku Sumber Tentang Metode-Metode Baru. (Cet. I; Jakarta: UI Press, 2002.

[6] Nana Saodih Sukmadinata, Metode Penelitian Kualitatif. (Bandung: PT. Remaja Rosdakarya, 2005.

[7] Nurla Isna Aunillah, Panduan Menerapkan Pendidikan Karakter di Sekolah, (Yogyakarta: Laksana, 2011.

[8] Ronny Hanitijo Soemitro, Metodologi Penelitian Hukum, Jurumetri dan Sosial, (Ghalia Indonesia: Jakarta, 2000.

[9] Rosyadi Rahmat, Pendidikan Islam dalam Pembentukan Karakter Anak Usia Dini (Konsep dan Praktek PAUD Islami), (Jakarta: Rajawali Pers, 2013.

[10] Zubaedi, Desain Pendidikan Karakter: Konsepsi dan Aplikasinya dalam Lembaga Pendidikan, (Jakarta: Kencana, 2011.

[11] Zuhairi, Metode Khusus Pendidikan Agama. (Surabaya: Usaha Nasional, 2003. 